\section{Coir Fiber and Bamboo Vinegar Improve the Quality of Composted Green Waste as a Growing Medium for Peacock Arrowroot}

\author{
Lu Zhang and Xiangyang Sun ${ }^{1}$
}

AdDitional INDEX WORDs. cation exchange capacity, coarseness index, electrical conductivity, photosynthetic pigment, plant root, porosity

\begin{abstract}
SUMMARY. Composting is considered an environmentally sound and economically viable alternative for the management of organic residues. Although compost product may be used as a peat substitute in soilless culture, it generally has poor physical structure, low nutrient content, high $\mathrm{pH}$, and high salt content. This study chose the coir fiber (CF) produced from coconut (Cocos nucifera) and bamboo vinegar (BV) produced from mottled bamboo (Phyllostachys bambusoides) as the media amendments, and evaluated the effects of CF (at $0 \%, 15 \%$, and $25 \%$ ) and/or BV (at $0 \%, 0.5 \%$, and $1.0 \%)$ on the physical, chemical, and microbiological properties of composted green waste (CGW) and on the growth of peacock arrowroot (Calatbea makoyana). The highest quality growing medium and the best growth of peacock arrowroot were obtained when CGW was amended with the combination of $15 \% \mathrm{CF}$ and $0.5 \% \mathrm{BV}$; the lowest quality medium and the least plant growth were obtained with nonamended CGW. The optimal combination not only improved particle-size distribution and adjusted bulk density (BD), porosity, and water-holding capacity (WHC) into ideal ranges, but it also decreased $\mathrm{pH}$ and electrical conductivity (EC) and increased microbial numbers, enzyme activities, and macro- and micronutrient contents in the CGW. Relative to the nonamended CGW, the optimal CGW reduced the BD from $0.58 \mathrm{~g} \cdot \mathrm{cm}^{-3}$ to $0.34 \mathrm{~g} \cdot \mathrm{cm}^{-3}$ and the $\mathrm{pH}$ from 8.05 to 5.61 , and increased the total porosity (TPS) from $48.1 \%$ to $77.0 \%$ and the WHC from $57.4 \%$ to $75.5 \%$; the optimal CGW increased shoot fresh weight, shoot dry weight, root fresh weight, root dry weight, plant height, crown breadth, number of leaves, and total root length by $83.9 \%, 77.8 \%, 66.1 \%, 65.1 \%, 63.6 \%$, $73.8 \%, 55.6 \%$, and $65.2 \%$, respectively.
\end{abstract}

$\mathrm{P}$ eat is commonly used as a component in soilless culture because of its favorable agronomic characteristics (Boldrin et al., 2010; FernandezHernandez et al., 2014; Zhang et al., 2013a). However, the decreasing availability and increasing price of peat has resulted in the need for inexpensive organic alternatives as the growing media (Eksi et al., 2015; Jayasinghe et al., 2010a, 2010b). Researchers have previously considered the use of compost as a substitute for peat in the media used to produce potted, ornamental plants (De Lucia et al., 2013; Jayasinghe, 2012b; Zhang et al., 2014, 2013b). However, compost frequently has undesirable qualities including poor physical

College of Forestry, Beijing Forestry University, P.O. Box 111, Beijing 100083, People's Republic of China

This work was supported by the Special Fund for Forest Scientific Research in the Public Welfare (NO. 201504205 ) and the Fundamental Research Funds for the Central Universities (No. BLX2015-07).

We thank Bruce Jaffee for his linguistic modification of this paper.

${ }^{1}$ Corresponding author. E-mail: sunxyl211@163. com.

doi: 10.21273/HORTTECH03626-16 structure, low availability of nutrients, high $\mathrm{pH}$, and high salt content (Cesaro et al., 2015; Ronga et al., 2016). There is substantial interest in using various organic amendments to improve the quality of compost product because such amendments may be effective and are readily available and inexpensive (Ahmad et al., 2012; Jayasinghe et al., 2009,2010 c).
CF is a plant-derived and readily available organic waste material that is obtained from the mesocarp (husk) of coconut; $\mathrm{CF}$ is one of the hardest plant fibers known (Aggarwal and Nirmala, 2012). CF also is hydrophilic, and because it is highly porous, it absorbs and retains both water and air (Koch and Barthlott, 2009). Although water-absorbing polymers are frequently added to peat-based media to increase the absorption of water that is applied to the dry media, these wetting agents are unnecessary in media that contain the appropriate amount of CF (Aggarwal and Nirmala, 2012). The relatively abundant and large pores on the surface of $\mathrm{CF}$ particles may explain why addition of CF increases water uptake, drainage, and gas exchange in soilless media (Carlile et al., 2015). Moreover, CF contains high concentrations of nutrients such as magnesium $(\mathrm{Mg})$ and potassium $(\mathrm{K})$, that may allow a reduction in the base fertilization of these elements in growing media (Hongpakdee and Ruamrungsri, 2015). Because of its high porosity, CF can also reduce nutrient loss from growing media and thereby increase the uptake of nutrients by potted plants (Koch and Barthlott, 2009). In addition, the amendment of media with CF has been reported to increase the flower quality and shelf life of potted french marigold (Tagetes patula) and celosia (Celosia cristata) (Awang and Ismail, 1997).

$\mathrm{BV}$ is a reddish-brown transparent liquid produced as a by-product during the pyrolysis of bamboo charcoal; it has more than 200 chemical components but acetic acid is the

\begin{tabular}{lllc}
\hline $\begin{array}{l}\text { Units } \\
\begin{array}{l}\text { To convert U.S. to SI, } \\
\text { multiply by }\end{array}\end{array}$ & U.S. unit & SI unit & $\begin{array}{l}\text { To convert SI to U.S., } \\
\text { multiply by }\end{array}$ \\
\hline 29.5735 & $\mathrm{fl} \mathrm{oz}$ & $\mathrm{mL}$ & 0.0338 \\
1.0432 & $\mathrm{fl} \mathrm{oz} / \mathrm{oz}$ & $\mathrm{mL} \cdot \mathrm{g}^{-1}$ & 0.9586 \\
3.7854 & gal & $\mathrm{L}$ & 0.2642 \\
2.54 & inch $(\mathrm{es})$ & $\mathrm{cm}$ & 0.3937 \\
25.4 & inch $(\mathrm{es})$ & $\mathrm{mm}$ & 0.0394 \\
6.4516 & inch & $\mathrm{cm}^{2}$ & 0.1550 \\
16.3871 & inch & $\mathrm{cm}^{3}$ & 0.0610 \\
0.4536 & $\mathrm{lb}$ & $\mathrm{kg}$ & 2.2046 \\
1 & $\mathrm{meq} / 100 \mathrm{~g}$ & $\mathrm{cmol} \cdot \mathrm{kg}^{-1}$ & 1 \\
1 & $\mathrm{mmho} / \mathrm{cm}^{3}$ & $\mathrm{mS} \cdot \mathrm{cm}^{-1}$ & 1 \\
28.3495 & $\mathrm{Oz}$ & $\mathrm{g}$ & 0.0353 \\
1.7300 & $\mathrm{Oz} / \mathrm{inch}^{3}$ & $\mathrm{~g} \cdot \mathrm{cm}^{-3}$ & 0.5780 \\
0.001 & $\mathrm{ppm}$ & $\mathrm{mg} \cdot \mathrm{g}^{-1}$ & 1000 \\
1 & $\mathrm{ppm}$ & $\mathrm{mg} \cdot \mathrm{kg}^{-1}$ & 1 \\
1 & $\mathrm{ppm}$ & $\mu \mathrm{g}^{-1}$ & 1 \\
$\left({ }^{\circ} \mathrm{F}-32\right) \div 1.8$ & ${ }^{\circ} \mathrm{F}$ & ${ }^{\circ} \mathrm{C}$ & $\left({ }^{\circ} \mathrm{C} \times 1.8\right)+32$
\end{tabular}

Hortlechnology · June 2017 27(3) 
dominant component, representing about $60 \%$ of the liquid ( $\mathrm{Mu}$ et al., 2004). The high concentration of organic acids in BV results in high antimicrobial activity; because of this property of $\mathrm{BV}$, it has been used as an insecticide or bactericide in ornamental horticulture media (Mun and $\mathrm{Ku}$, 2010). BV can also promote plant growth because of its high contents of various organic acids and its effects on the $\mathrm{pH}$ of growing media (Chen et al., 2010). Moreover, BV has a high level of macro- and micronutrients, vitamins, and enzymes that could increase the initial nutrient content of growing media (Rattanawut, 2014). $\mathrm{BV}$ has also been used as an environmentally safe substance to accelerate seed germination and stimulate plant growth (Mu et al., 2004; Mun and $\mathrm{Ku}, 2010)$.

Although research has indicated that $\mathrm{CF}$ or $\mathrm{BV}$ improve growing media properties and plant growth, the combined effects of CF and BV addition on the growth of the potted ornamental plant peacock arrowroot in CGW have not been reported. In China, peacock arrowroot is a popular ornamental plant that is produced in pots in greenhouses (Zhang et al., 2014). Peacock arrowroot belongs to the Marantaceae or arrowroot family and is a perennial evergreen herb (Tran et al., 2013). Greenhouse production of peacock arrowroot and other ornamental plants requires a suitable growing medium, and peacock arrowroot grows best in an acidic growing medium or humic soil. It also requires a growing medium that has high porosity, that is well drained but retains sufficient water, and that is rich in nutrients (Zhang et al., 2013a).

The objective of current study was to determine the effects of adding various quantities of $\mathrm{CF}$ and/or BV on the physical, chemical, microbiological, and nutritional properties of CGW and on the growth parameters and nutrient contents of the ornamental plant peacock arrowroot.

\section{Materials and methods}

SELECTION AND PREPARATION OF RAW MATERIALS. Mature CGW was purchased from the Beijing Jingpuyuan Biological Engineering Co. (Beijing, China) and was made from fallen leaves and branch cuttings generated by urban landscape maintenance. CGW is considered mature and nonphytotoxic when it has a germination index $>80 \%$, carbon:nitrogen $(\mathrm{C}$ : $\mathrm{N})$ ratio $<20, \mathrm{EC}<4 \mathrm{mS} \cdot \mathrm{cm}^{-1}$, and cation exchange capacity (CEC) $>60.0$ $\mathrm{cmol} \cdot \mathrm{kg}^{-1}$ (Zhang et al., 2013a, 2014). The CGW was air-dried (3\% to $5 \%$ moisture content) before it was used. In the present study, the CGW was mixed with different quantities of $\mathrm{CF}$ and/or BV. CF and BV were both purchased from the Beijing Kaiyin Organic Fertilizer Production Co. (Beijing, China). CF was air-dried and then cut with a grass-cutting multifunctional shredder (model 9ZF-500B; Qizheng Mechanical Equipment Manufacturing Co., Guangdong, China) to a length of 3 to $5 \mathrm{~cm}$, a length that was reported to optimize media properties (Aggarwal and Nirmala, 2012). BV was diluted in $500 \mathrm{~L}$ of water [water hardness $\leq 10 \mathrm{~d}$, $\mathrm{pH}$ between 6.8 and 7.1, and sodium chloride $(\mathrm{NaCl})$ content $<2 \mathrm{mmol} \cdot \mathrm{L}^{-1}$ ] before it was added to the CGW; $2 \mathrm{~mL}$ of BV was added per $100 \mathrm{~kg}$ of CGW (dry weight). The amount of BV added in the nine treatments was calculated according to the Table 2 . The physical and chemical properties of the initial $\mathrm{CGW}, \mathrm{CF}$, and $\mathrm{BV}$ are presented in Table 1 .

Preparation of growing MEDIA. CF and/or BV were added to the CGW as indicated by the nine treatments described in Table 2 . CGW without CF or BV (treatment TI) was used as the control. First, the different quantities of CGW and CF needed for each treatment were mechanically blended with a mini excavator (model DLS830-9B; Hecheng Engineering Machinery Co., Shanghai, China). Second, the different quantities of $B V$ required for each treatment were mixed thoroughly with $2 \mathrm{~L}$ of water, and the diluted BV was then evenly sprayed on the CGW according to Table 2. The materials were then mixed again and air-dried before they were used in the plant growth experiment (Zhang et al., 2013b, 2014). A fertilized control (in which the compost was amended with conventional commercial fertilizers) was not included in this study.

Physical AND CHEMICAL ANALYSES OF GROWING MEDIA. BD, WHC, total porosity, aeration porosity (AP), and water-holding porosity (WHP) were determined as described by Zhang et al. (2013a). An aluminium box $\left(200 \mathrm{~cm}^{3}\right)$ without a lid $\left(\mathrm{M}_{0}\right)$ was filled with air-dried growing media (without compaction) and was weighed $\left(M_{1}\right)$. After media were saturated by submergence in deionized water for $24 \mathrm{~h}$, they were weighed again $\left(\mathrm{M}_{2}\right)$, and the aluminium box was covered with gauze. The aluminium box with saturated growing media was then placed upside down on a screen until the water stopped dripping from the bottom (after about $4 \mathrm{~h}$ ). The gauze was removed, and the aluminium box was weighed again $\left(\mathrm{M}_{3}\right)$. Finally, the aluminium box with growing media was oven-dried at $65^{\circ} \mathrm{C}$ to constant weight $\left(\mathrm{M}_{4}\right)$. The physical properties of the growing media were calculated with the following formulas: BD (grams per cubic centimeter $)=\left(M_{4}--M_{0}\right) / 200$; WHC $(\%)=\left[\left(\mathrm{M}_{3}-\mathrm{M}_{1}\right) \times 100\right] /\left(\mathrm{M}_{1}-\right.$ $\left.\mathrm{M}_{0}\right) ; \operatorname{TPS}(\%)=\left[\left(\mathrm{M}_{2}-\mathrm{M}_{4}\right) \times 100\right] /$ $200 ; \mathrm{AP}(\%)=\left[\left(\mathrm{M}_{2}-\mathrm{M}_{3}\right) \times 100\right] /$ 200; WHP $(\%)=$ TPS - AP .

The particle-size distribution of the growing media was determined according to Gabhane et al. (2012) and Zhang et al. (2013a). In brief, airdried media were shaken on sieves with openings of $0.10,0.25,0.50$, $1.00,2.00$, and $12 \mathrm{~mm}$ for $3 \mathrm{~min}$. The material retained on each sieve was weighed. The coarseness index (CI), expressed as a percentage (based on air-dried weight) of particles $>1 \mathrm{~mm}$, was also determined (Jayasinghe, 2012a).

$\mathrm{pH}$ and EC were determined in a $1: 10(\mathrm{w} / \mathrm{v})$ mixture of sample:water using a $\mathrm{pH} / \mathrm{EC}$ meter (MP521; Pingxuan Scientific Instruments, Shanghai, China); CEC was measured at $\mathrm{pH} 7.0$ with ammonium acetate (Zhang et al., 2013a). Total organic carbon (TOC) was determined with a TOC analyser (Liqui TOC; Kyoto Electronics Manufacturing, Kyoto, Japan); total Kjeldahl nitrogen $(\mathrm{TKN})$ was analyzed by the Kjeldahl method with an automatic Kjeldahl apparatus (KDY-9830; Beijing UNITA NewMargin Equipment, Beijing, China); total phosphorus was estimated by the Anti-Mo-Sb spectrophotometry method using a spectrophotometer (model 721, Pingxuan Scientific Instruments); total potassium was determined by flame photometry using a 425 flame photometer (Shanghai, China) (Zhang et al., 2013a, 2013b). For determination of micro- and macronutrients, samples 
Table 1. Selected physicochemical properties of CF, BV, CGW, and the nine growing media (treatments T1-T9).

\begin{tabular}{|c|c|c|c|c|c|}
\hline \multirow[b]{3}{*}{ Treatment $^{\mathrm{z}}$} & \multicolumn{5}{|c|}{ Physical properties $^{\mathrm{y}}$} \\
\hline & $\mathrm{BD}\left(\mathrm{g} \cdot \mathrm{cm}^{-3}\right)$ & WHC (\%) & TPS (\%) & $\mathrm{AP}(\%)$ & WHP (\%) \\
\hline & \multicolumn{5}{|c|}{ Mean (SD) } \\
\hline BV & - & - & - & - & - \\
\hline $\mathrm{Tl}$ & $0.5807(0.0243) \mathrm{a}^{\mathrm{x}}$ & $57.40(0.20) \mathrm{i}$ & $48.09(0.14) \mathrm{i}$ & $11.19(0.12) \mathrm{i}$ & $36.90(0.27) \mathrm{i}$ \\
\hline $\mathrm{T} 2$ & $0.5421(0.0111) b$ & $58.22(0.11) \mathrm{h}$ & $49.23(0.21) \mathrm{h}$ & $12.18(0.20) \mathrm{h}$ & $37.05(0.68) \mathrm{h}$ \\
\hline T5 & $0.3572(0.0343) \mathrm{e}$ & $72.39(0.09) \mathrm{e}$ & $74.24(0.27) \mathrm{e}$ & $22.11(0.47) \mathrm{e}$ & $52.13(0.32) \mathrm{e}$ \\
\hline T6 & $0.3350(0.0240) \mathrm{f}$ & $75.46(0.27) \mathrm{d}$ & $76.95(0.09) \mathrm{d}$ & $24.69(0.21) \mathrm{d}$ & $52.26(0.43) \mathrm{d}$ \\
\hline T7 & $0.2486(0.0192) \mathrm{g}$ & $81.90(0.18) \mathrm{c}$ & $83.03(0.07) \mathrm{c}$ & $27.52(0.08) \mathrm{c}$ & $55.51(0.08) \mathrm{c}$ \\
\hline T8 & $0.2359(0.0427) \mathrm{h}$ & $83.01(0.24) b$ & $85.34(0.16) \mathrm{b}$ & $27.76(0.12) b$ & $57.58(0.54) \mathrm{b}$ \\
\hline T9 & $0.2031(0.0103) \mathrm{i}$ & $83.28(0.13) \mathrm{a}$ & $89.02(0.20) \mathrm{a}$ & $29.78(0.33) \mathrm{a}$ & $59.24(0.17) \mathrm{a}$ \\
\hline $\mathrm{CF}$ & $6.91(0.08)$ & $0.61(0.04)$ & $167.22(0.79)$ & $20.11(0.54)$ & - \\
\hline BV & $3.10(0.03)$ & $0.30(0.02)$ & - & - & - \\
\hline $\mathrm{Tl}$ & $8.05(0.21) \mathrm{a}$ & $1.08(0.09) \mathrm{a}$ & $54.01(0.23) \mathrm{i}$ & $15.12(0.37) \mathrm{i}$ & - \\
\hline $\mathrm{T} 2$ & $7.11(0.34) \mathrm{d}$ & $0.70(0.10) \mathrm{d}$ & $86.37(0.75) \mathrm{f}$ & $21.45(0.43) \mathrm{f}$ & - \\
\hline $\mathrm{T} 3$ & $6.70(0.09) \mathrm{e}$ & $0.60(0.05) \mathrm{e}$ & $92.82(0.42) \mathrm{e}$ & $22.10(0.60) \mathrm{e}$ & - \\
\hline $\mathrm{T} 4$ & $7.84(0.17) \mathrm{b}$ & $1.01(0.08) b$ & $75.29(0.35) \mathrm{h}$ & $17.39(0.34) \mathrm{h}$ & - \\
\hline T5 & $6.23(0.30) \mathrm{f}$ & $0.50(0.03) \mathrm{f}$ & $127.77(1.04) \mathrm{d}$ & $26.22(0.22) \mathrm{d}$ & - \\
\hline T6 & $5.61(0.19) \mathrm{h}$ & $0.43(0.01) \mathrm{g}$ & $138.03(0.92) b$ & $30.08(0.09) \mathrm{b}$ & - \\
\hline $\mathrm{T} 7$ & $7.62(0.43) c$ & $0.96(0.01) \mathrm{c}$ & $81.64(0.61) \mathrm{g}$ & $18.42(0.18) \mathrm{g}$ & - \\
\hline T8 & $6.01(0.28) \mathrm{g}$ & $0.48(0.08) \mathrm{f}$ & $131.87(0.59) \mathrm{c}$ & $27.63(0.50) \mathrm{c}$ & - \\
\hline T9 & $5.34(0.11) \mathrm{i}$ & $0.40(0.06) \mathrm{h}$ & $142.62(0.80) \mathrm{a}$ & $34.39(0.44) \mathrm{a}$ & - \\
\hline $\mathrm{Tl}$ & $2.12(0.19) \mathrm{i}$ & $0.20(0.03) \mathrm{i}$ & $0.38(0.35) \mathrm{h}$ & $0.93(0.10) \mathrm{h}$ & $0.21(0.13) \mathrm{i}$ \\
\hline $\mathrm{T} 2$ & $2.75(0.08) \mathrm{f}$ & $0.94(0.31) \mathrm{f}$ & $0.72(0.10) \mathrm{f}$ & $1.38(0.07) \mathrm{e}$ & $0.46(0.09) \mathrm{f}$ \\
\hline $\mathrm{T} 3$ & $2.94(0.10) \mathrm{e}$ & $1.08(0.08) \mathrm{e}$ & $0.83(0.22) \mathrm{e}$ & $1.41(0.09) \mathrm{e}$ & $0.52(0.04) \mathrm{e}$ \\
\hline $\mathrm{T} 4$ & $2.29(0.06) \mathrm{h}$ & $0.37(0.06) \mathrm{h}$ & $0.45(0.05) \mathrm{g}$ & $1.09(0.14) \mathrm{g}$ & $0.28(0.08) \mathrm{h}$ \\
\hline $\mathrm{T} 5$ & $3.20(0.24) \mathrm{d}$ & $1.43(0.17) \mathrm{d}$ & $1.19(0.09) \mathrm{d}$ & $1.67(0.18) \mathrm{d}$ & $0.69(0.10) \mathrm{d}$ \\
\hline T6 & $3.89(0.39) \mathrm{b}$ & $1.71(0.20) b$ & $1.33(0.14) b$ & $1.80(0.06) \mathrm{b}$ & $0.82(0.05) b$ \\
\hline T7 & $2.40(0.11) \mathrm{g}$ & $0.50(0.04) \mathrm{g}$ & $0.47(0.06) \mathrm{g}$ & $1.17(0.22) \mathrm{f}$ & $0.32(0.12) \mathrm{g}$ \\
\hline T8 & $3.31(0.05) \mathrm{c}$ & $1.56(0.12) \mathrm{c}$ & $1.26(0.20) \mathrm{c}$ & $1.73(0.14) \mathrm{c}$ & $0.77(0.11) \mathrm{c}$ \\
\hline \multirow[t]{3}{*}{ T9 } & $4.18(0.24) \mathrm{a}$ & $1.89(0.25) \mathrm{a}$ & $1.40(0.11) \mathrm{a}$ & $1.94(0.11) \mathrm{a}$ & $0.91(0.07) \mathrm{a}$ \\
\hline & \multicolumn{5}{|c|}{ Micronutrients $^{\mathrm{y}}$} \\
\hline & $S(\%)$ & $\mathrm{Fe}\left(10^{-3} \%\right)$ & $\mathrm{B}\left(10^{-3} \%\right)$ & $\operatorname{Mo}\left(10^{-3} \%\right)$ & - \\
\hline Treatment & \multicolumn{5}{|c|}{ Mean (SD) } \\
\hline $\mathrm{CF}$ & $10.05(0.23)$ & $20.32(0.18)$ & $1.64(0.35)$ & $7.78(0.38)$ & - \\
\hline BV & - & - & - & - & - \\
\hline $\mathrm{Tl}$ & $6.22(0.27) \mathrm{i}$ & $14.01(0.10) \mathrm{i}$ & $1.18(0.09) \mathrm{i}$ & $5.94(0.21) \mathrm{i}$ & - \\
\hline $\mathrm{T} 2$ & $9.28(0.19) \mathrm{f}$ & $18.12(0.29) \mathrm{f}$ & $1.67(0.16) \mathrm{f}$ & $8.22(0.14) \mathrm{f}$ & - \\
\hline $\mathrm{T} 3$ & $10.02(0.11) \mathrm{e}$ & $19.40(0.15) \mathrm{e}$ & $1.75(0.13) \mathrm{e}$ & $8.73(0.30) \mathrm{e}$ & - \\
\hline $\mathrm{T} 4$ & $7.09(0.08) \mathrm{h}$ & $15.13(0.20) \mathrm{h}$ & $1.24(0.26) \mathrm{h}$ & $6.24(0.07) \mathrm{h}$ & - \\
\hline $\mathrm{T} 5$ & $12.05(0.32) \mathrm{d}$ & $23.38(0.33) \mathrm{d}$ & $1.93(0.31) \mathrm{d}$ & $10.82(0.35) \mathrm{d}$ & - \\
\hline T6 & $13.17(0.20) b$ & $25.62(0.48) b$ & $2.07(0.16) b$ & $11.39(0.26) b$ & - \\
\hline $\mathrm{T} 7$ & $7.33(0.24) \mathrm{g}$ & $16.00(0.23) \mathrm{g}$ & $1.36(0.05) \mathrm{g}$ & $6.75(0.12) \mathrm{g}$ & - \\
\hline
\end{tabular}


Table 1. (Continued) Selected physicochemical properties of CF, BV, CGW, and the nine growing media (treatments TIT9).

\begin{tabular}{|c|c|c|c|c|c|}
\hline \multirow[b]{3}{*}{ Treatment } & \multicolumn{5}{|c|}{ Micronutrients $^{\mathrm{y}}$} \\
\hline & S (\%) & $\mathrm{Fe}\left(10^{-3} \%\right)$ & $\mathrm{B}\left(10^{-3} \%\right)$ & $\operatorname{Mo}\left(10^{-3} \%\right)$ & - \\
\hline & & & Mean (SD) & & \\
\hline T8 & $12.76(0.15) c$ & $24.09(0.56) \mathrm{c}$ & $2.02(0.37) \mathrm{c}$ & $11.18(0.43) \mathrm{c}$ & - \\
\hline T9 & $13.85(0.06) \mathrm{a}$ & $26.13(0.87) \mathrm{a}$ & $2.19(0.48) \mathrm{a}$ & $11.62(0.10) \mathrm{a}$ & - \\
\hline
\end{tabular}

$\mathrm{CF}=$ coir fiber $\mathrm{BV}=$ bamboo vinegar $\mathrm{CGW}=$ composted green waste $; \mathrm{BD}=$ bulk density, $\mathrm{WHC}=$ water-holding capacity; $\mathrm{TPS}=$ total porosity $\mathrm{AP}=\mathrm{aeration}$ porosity; $\mathrm{WHP}=$ water-holding porosity; $\mathrm{EC}=$ electrical conductivity $\left[\right.$ at $\left.25^{\circ} \mathrm{C}\left(77.0^{\circ} \mathrm{F}\right)\right] ; \mathrm{CEC}=$ cation-exchange capacity $(\mathrm{pH}=7.0) ; \mathrm{TOC}=$ total organic carbon; TKN $=$ total $\mathrm{Kjeldahl}$ nitrogen; $\mathrm{TP}=$ total phosphorus; $\mathrm{TK}=$ total potassium; $\mathrm{Ca}=$ calcium; $\mathrm{Mg}=$ magnesium $; \mathrm{S}=$ sulfur; $\mathrm{Fe}=$ iron; $\mathrm{B}=\mathrm{boron} ; \mathrm{Mo}=\mathrm{molybdenum}$.

${ }^{\mathrm{z}} \mathrm{Tl}=$ nonamended $\mathrm{CGW}$ treatment, $\mathrm{T} 2=0.5 \% \mathrm{BV}, \mathrm{T} 3=1.0 \% \mathrm{BV}, \mathrm{T} 4=15 \% \mathrm{CF}, \mathrm{T} 5=15 \% \mathrm{CF}+0.5 \% \mathrm{BV}, \mathrm{T} 6=15 \% \mathrm{CF}+1.0 \% \mathrm{BV}, \mathrm{T} 7=25 \% \mathrm{CF}, \mathrm{T} 8=25 \% \mathrm{CF}+0.5 \% \mathrm{BV}, \mathrm{T} 9=$ $25 \% \mathrm{CF}+1.0 \% \mathrm{BV}$.

${ }^{\mathrm{y}} 1 \mathrm{~g} \cdot \mathrm{cm}^{-3}=0.5780 \mathrm{oz} / \mathrm{inch}^{3}, 1 \mathrm{mS} \cdot \mathrm{cm}^{-1}=1 \mathrm{mmho} / \mathrm{cm}, 1 \mathrm{cmol} \cdot \mathrm{kg}^{-1}=1 \mathrm{meq} / 100 \mathrm{~g}$.

${ }^{\mathrm{x}}$ Values are mean $\pm \mathrm{SD}(\mathrm{n}=3)$. Means in a column followed by the same letter are not significantly different at $P \leq 0.05$ by least significant difference.

${ }^{\mathrm{w}} \mathrm{IR}=$ ideal range, according to Zhang et al. (2013a, 2014).

Table 2. Orthogonal design $\mathrm{L}_{9}\left(3^{4}\right)$ of the experiment to determine how the nine treatments affected the properties of the growing media and the growth parameters and nutrient contents of peacock arrowroot.

\begin{tabular}{|c|c|c|}
\hline Treatment $^{\mathrm{z}}$ & $\begin{array}{l}\text { CF content } \\
\text { in CGW } \\
(\% \text { dry wt })^{z}\end{array}$ & $\begin{array}{l}\text { BV content } \\
\text { in CGW } \\
(\% \text { dry wt })^{z}\end{array}$ \\
\hline $\mathrm{Tl}$ & 0 & 0 \\
\hline $\mathrm{T} 2$ & 0 & 0.5 \\
\hline $\mathrm{T} 3$ & 0 & 1.0 \\
\hline $\mathrm{T} 4$ & 15 & 0 \\
\hline $\mathrm{T} 5$ & 15 & 0.5 \\
\hline T6 & 15 & 1.0 \\
\hline T7 & 25 & 0 \\
\hline $\mathrm{T} 8$ & 25 & 0.5 \\
\hline T9 & 25 & 1.0 \\
\hline
\end{tabular}

$\mathrm{CGW}=$ composted green waste; $\mathrm{CF}=$ coir fiber; $\mathrm{BV}=$ bamboo vinegar.

${ }^{\mathrm{z}} \mathrm{T} 1=$ nonamended treatment, $\mathrm{T} 2=0.5 \% \mathrm{BV}, \mathrm{T} 3=$ $1.0 \% \mathrm{BV}, \mathrm{T} 4=15 \% \mathrm{CF}, \mathrm{T} 5=15 \% \mathrm{CF}+0.5 \% \mathrm{BV}, \mathrm{T} 6=$ $15 \% \mathrm{CF}+1.0 \% \mathrm{BV}, \mathrm{T} 7=25 \% \mathrm{CF}, \mathrm{T} 8=25 \% \mathrm{CF}+0.5 \%$ $\mathrm{BV}, \mathrm{T} 9=25 \% \mathrm{CF}+1.0 \% \mathrm{BV}$.

were digested with sulfuric acid, and the digested liquid was analyzed by inductively coupled plasma mass spectrometry [ICP-MS (Concord Technology, Concord, NH)] (Zhang et al., 2014).

Microbiological analyses of GROWING MEDIA. The abundances of culturable bacteria, actinomycetes, and fungi in the growing media were determined by serial dilution and plating as described by Shi et al. (2006) and Sen and Chandra (2009).

The activities of the following enzymes that reflect microbial activities were determined according to the methods of Du et al. (2015): catalase, invertase, urease, proteinase, phosphatase, and $\beta$-glucosidase.

Plant growth experiment. The experiment was conducted in a controlled-temperature greenhouse covered with polycarbonate at the
Shunyi District Nursery of the Beijing Green Garden Group (Beijing, China) from 11 Apr. to 11 Nov. 2015. The greenhouse temperature ranged from 20 to $25^{\circ} \mathrm{C}$ in the day and from 18 to $20{ }^{\circ} \mathrm{C}$ at night, with $65 \%$ to $75 \%$ relative humidity and $18 \mathrm{~mol} \cdot \mathrm{m}^{-2} \cdot \mathrm{d}^{-1}$ light intensity (Zhang et al., 2014).

Peacock arrowroot seedlings were produced by tissue culture. When the plants were about $15 \mathrm{~cm}$ tall and had a fresh shoot weight of about $42 \mathrm{~g}$ and a fresh root weight of about $15 \mathrm{~g}$, they were transplanted into $2000-\mathrm{cm}^{3}$ pots (one plant per pot) that contained the air-dried growing media (treatments T1-T9), which had been added without compaction. Each of the nine growing media was represented by 30 replicate pots. The 270 pots were arranged in a completely randomized design on the benches in the greenhouse. The pots were then slowly watered with optimized tap water (water hardness $\leq 10 \mathrm{~d}, \mathrm{pH}$ between 6.8 and 7.1 , and $\mathrm{NaCl}$ content $<2 \mathrm{mmol} \cdot \mathrm{L}^{-1}$ ) until water drained from the holes in the bottom of the pots (Zhang et al., 2014). During growth process, the plants were irrigated as needed, and the volume and timing of irrigation were identical for all treatments. Neither pesticides nor fertilizers were applied before or during the study.

The experiment was ended when the plants had grown to commercial size, which was 7 months after planting (Zhang et al., 2013b, 2014). All of the plants were harvested, and their growth parameters and nutrient contents were determined as described in the following section.

PEACOCK ARROWROOT GROWTH PARAMETERS AND NUTRIENT CONTENTS. Growth parameters and nutrient contents of peacock arrowroot at commercial size were determined for 30 plants per treatment (Zhang et al., 2013b, 2014). Plant height, crown width, leaf number, relative leaf water content, fresh and dry weights of shoots and roots, and total chlorophyll (including chlorophylls $a$ and $b$ and carotenoids) of fresh leaves were determined as described by Zhang et al. (2013b, 2014). Plant height was measured with from media surface to the tops of the three highest leaves for each plant; the three values were averaged to obtain one value of height per plant. Crown width was measured twice for each plant (the second measurement was at a right angle to the first), and the results were averaged. Leaf number was also recorded. Shoots and roots were then thoroughly washed with deionized water and dried with paper towels, and fresh weights were determined. Total chlorophyll (including chlorophylls $\mathrm{a}$ and $\mathrm{b}$ and carotenoids) was then quantified according to the methods of Zhang et al. (2013b, 2014). Anti-Mo-Sb spectrophotometry was used for extinction measurements of the alcohol (95\%) extracts of different pigments. Measurements were performed on four randomly chosen leaves per replicate; each measurement was performed twice, and sample weight was constant for all plants and treatments; the mean per replicate plant was used for statistical analysis. Fresh roots were scanned to analyze root properties (total root length, total root surface area, average root diameter, total root volume, and total number of root tips) using image analysis software (WinRHIZO-EC; Regent Instruments, Ottawa, ON, Canada). The length of the longest root was also measured. Shoots and 
roots of the same plants were subsequently oven-dried at $90{ }^{\circ} \mathrm{C}$ for $30 \mathrm{~min}$ and then at $65^{\circ} \mathrm{C}$. When constant weights were obtained, dry weights were recorded. Finally, ovendried shoots of plants were crushed in a small grinder and passed through a $1.0-\mathrm{mm}$ soil sieve for analysis of nutrient contents. For determination of the macro- and micronutrient contents in the leaves, the oven-dried leaves were digested with sulfuric acid, and the digested liquid was analyzed by ICP-MS (Concord Technology) (Zhang et al., 2014). Relative leaf water content $(\%)=[$ (fresh weight dry weight)/(turgid weight - dry weight) $] \times 100$.

Statistical analyses. Although the experiment had an orthogonal design, the study was more concerned with the effects of the nine treatments than with the main effects and interactions between main effects (Zhang et al., 2013a, 2013b, 2014). One-way analyses of variance (ANOVAs) were therefore used to determine how the nine treatments affected the properties of the growing media and the growth parameters and nutrient contents of peacock arrowroot. When ANOVAs were significant for main effects, means were separated with a least significant difference test. All statistical analyses were performed with SPSS (version 16.0; IBM Corp., Armonk, NY).

\section{Results and discussion}

BD, WHC, AND POROSITY OF GROWING MEDIA. The main physical properties of the nine growing media are listed in Table 1. BD was significantly $(P<0.05)$ reduced by addition of $\mathrm{CF}$ and $\mathrm{BV}$, either alone or in combination, but was within the ideal range $\left(<0.4000 \mathrm{~g} \cdot \mathrm{cm}^{-3}\right)$ suggested by Zhang et al. $(2014,2013 a)$ in treatments T4 (15\% CF), T5 (15\% CF + $0.5 \% \mathrm{BV})$, T6 (15\% CF + $1.0 \% \mathrm{BV})$, T7 $(25 \% \mathrm{CF}), \mathrm{T} 8(25 \% \mathrm{CF}+0.5 \%$ $\mathrm{BV})$, and $\mathrm{T} 9(25 \% \mathrm{CF}+1.0 \% \mathrm{BV})$. In contrast, addition of $\mathrm{CF}$ or $\mathrm{BV}$, and especially the combined addition of $\mathrm{CF}$ and $\mathrm{BV}$, greatly $(P<0.05)$ increased WHC, TPS, AP, and WHP. $\mathrm{WHC}$ and $\mathrm{AP}$ values were within the acceptable ranges for treatments $\mathrm{T} 5$ $(15 \% \mathrm{CF}+0.5 \% \mathrm{BV}), \mathrm{T} 6(15 \% \mathrm{CF}+$ $1.0 \% \mathrm{BV}), \mathrm{T} 7(25 \% \mathrm{CF}), \mathrm{T} 8(25 \%$ $\mathrm{CF}+0.5 \% \mathrm{BV})$, and $\mathrm{T} 9(25 \% \mathrm{CF}+$ $1.0 \% \mathrm{BV}$ ), and TPS and WHP values were within the optimal ranges for treatments T4 $(15 \% \mathrm{CF}), \mathrm{T} 5$ (15\% CF $+0.5 \% \mathrm{BV}), \mathrm{T} 6(15 \% \mathrm{CF}+1.0 \% \mathrm{BV})$, T7 (25\% CF), T8 $(25 \% \mathrm{CF}+0.5 \%$ $\mathrm{BV})$, and $\mathrm{T} 9(25 \% \mathrm{CF}+1.0 \% \mathrm{BV})$. Therefore, in terms of providing a suitable physical environment for plant growth, the growing media of treatments $\mathrm{T} 5(15 \% \mathrm{CF}+0.5 \% \mathrm{BV})$, T6 $(15 \% \mathrm{CF}+1.0 \% \mathrm{BV}), \mathrm{T} 8(25 \%$ $\mathrm{CF}+0.5 \% \mathrm{BV})$, and $\mathrm{T} 9(25 \% \mathrm{CF}+$ $1.0 \% \mathrm{BV}$ ) (all of which were amended with a combination of $\mathrm{CF}$ and $\mathrm{BV}$ ) and treatment T7 $(25 \% \mathrm{CF})$ (which was amended with $\mathrm{CF}$ alone) were better than those of the other treatments.

The above results indicate that addition of CF and/or BV not only reduced CGW compaction but also increased CGW water retention and oxygen availability. In particular, the combined addition of appropriate proportions of $\mathrm{CF}$ and $\mathrm{BV}$ caused the CGW to have optimal values for $\mathrm{BD}$, WHC, TPS, AP, and WHP. These changes could enhance gas exchange, water retention, and water drainage and thereby enhance plant growth in the CGW (Brito et al., 2015; Jayasinghe et al., 2009; Young et al., 2014). CF addition increased not only the volume of the medium occupied by air space but also its water retention because $\mathrm{CF}$ is a lightweight material with a wide range of pore sizes (Hongpakdee and Ruamrungsri, 2015; Koch and Barthlott, 2009). The high concentration of organic acids and hydrophilic groups in the BV could also cause the individual substrate granules to bind together and thereby contribute to the formation of appropriate porosity in the CGW. These results agree with those of Mun and $\mathrm{Ku}$ (2010) and Zhang et al. (2013a, 2013b).

\section{Particle-size distribution} AND CI OF GROWING MEDIA. The particle-size distributions and CIs of the nine growing media are listed in Table 3. Addition of CF or BV individually or in combination significantly $(P<0.05)$ increased the percentage of particles between 0.25 and $2.00 \mathrm{~mm}$ and the CI values. This was especially true for treatments $\mathrm{T} 5$ $(15 \% \mathrm{CF}+0.5 \% \mathrm{BV}), \mathrm{T} 6(15 \% \mathrm{CF}+$ $1.0 \% \mathrm{BV}), \mathrm{T} 8(25 \% \mathrm{CF}+0.5 \% \mathrm{BV})$, and $\mathrm{T} 9(25 \% \mathrm{CF}+1.0 \% \mathrm{BV})$ (the

Table 3. Effects of CF and/or BV addition on the particle-size distribution and CI of the nine growing media (treatments T1-T9).

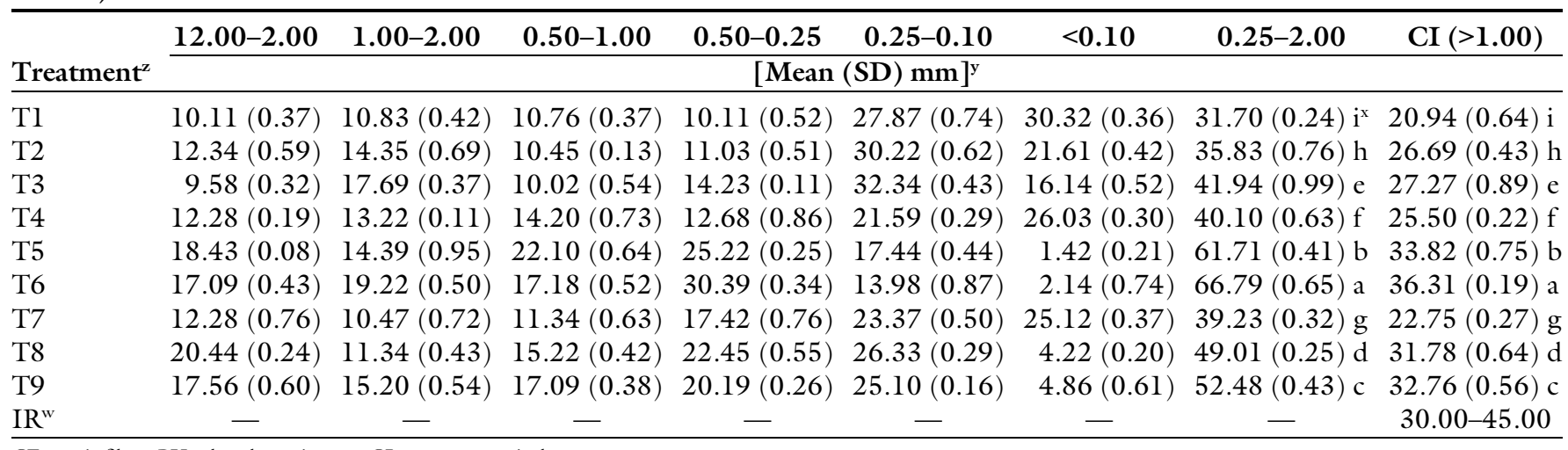

$\mathrm{CF}=$ coir fiber; $\mathrm{BV}=$ bamboo vinegar; $\mathrm{CI}$ = coarseness index.

The values for particle-size distribution and CI indicate the percentage in each size range (in millimeters). Values in each row (excluding values for $0.25-2.00$ and $>1.00 \mathrm{~mm}$ ) add to $100 \%$.

${ }^{\mathrm{z}} \mathrm{Tl}=$ nonamended treatment, $\mathrm{T} 2=0.5 \% \mathrm{BV}, \mathrm{T} 3=1.0 \% \mathrm{BV}, \mathrm{T} 4=15 \% \mathrm{CF}, \mathrm{T} 5=15 \% \mathrm{CF}+0.5 \% \mathrm{BV}, \mathrm{T} 6=15 \% \mathrm{CF}+1.0 \% \mathrm{BV}, \mathrm{T} 7=25 \% \mathrm{CF}, \mathrm{T} 8=25 \% \mathrm{CF}+0.5 \% \mathrm{BV}, \mathrm{T} 9=25 \%$ $\mathrm{CF}+1.0 \% \mathrm{BV}$.

${ }^{\mathrm{y}}$ Values are mean $\pm \mathrm{SD}(\mathrm{n}=3) ; 1 \mathrm{~mm}=0.0394$ inch.

${ }^{x}$ For $0.25-2.00$ and CI, means in a column followed by the same letter are not significantly different at $P \leq 0.05$ by least significant difference.

w $I R=$ ideal range according to Jayasinghe (2012a). 

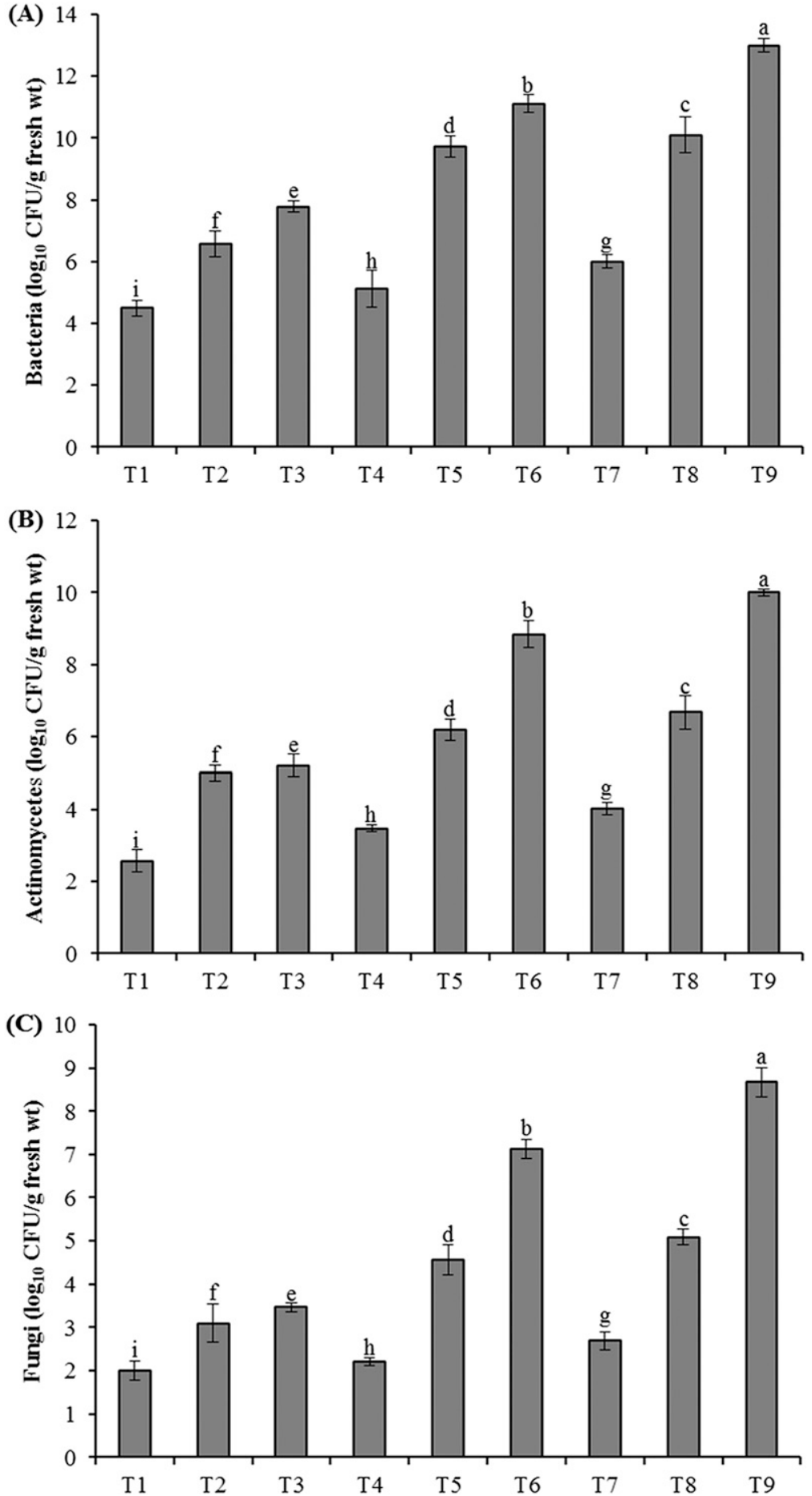

Fig. 1. Effects of coir fiber (CF) and bamboo vinegar (BV) on the numbers of culturable bacteria (A), actinomycetes (B), and fungi $(C)$ in the nine growing media: $\mathrm{T} 1=$ nonamended treatment, $\mathrm{T} 2=0.5 \% \mathrm{BV}, \mathrm{T} 3=1.0 \% \mathrm{BV}, \mathrm{T} 4=15 \% \mathrm{CF}, \mathrm{T} 5=15 \%$ $\mathrm{CF}+0.5 \% \mathrm{BV}, \mathrm{T} 6=15 \% \mathrm{CF}+1.0 \% \mathrm{BV}, \mathrm{T} 7=25 \% \mathrm{CF}, \mathrm{T} 8=25 \% \mathrm{CF}+0.5 \% \mathrm{BV}$, $\mathrm{T} 9=25 \% \mathrm{CF}+1.0 \% \mathrm{BV}$. Values are mean $\pm \mathrm{SD}(\mathrm{n}=30)$. Within each panel, means followed by different letters are significantly different according to least significant difference at $P \leq 0.05 ; 1$ colony forming unit $(\mathrm{CFU}) / \mathrm{g}=28.3495 \mathrm{CFU} / \mathrm{oz}$.

combined addition of $\mathrm{CF}$ and $\mathrm{BV}$ ). The increase in particles between 0.25 and $2.0 \mathrm{~mm}$ was greatest in treatment T6 $(15 \% \mathrm{CF}+1.0 \% \mathrm{BV})$ and smallest in treatment $\mathrm{Tl}$ (the nonamended treatment). The CIs of treatments T5 $(15 \% \mathrm{CF}+0.5 \% \mathrm{BV}), \mathrm{T} 6(15 \%$ $\mathrm{CF}+1.0 \% \mathrm{BV}), \mathrm{T} 8(25 \% \mathrm{CF}+0.5 \%$ $\mathrm{BV})$, and T9 $(25 \% \mathrm{CF}+1.0 \% \mathrm{BV})$ were within the established ideal range (30\% to $45 \%)$ (Jayasinghe, 2012a).

The particle-size distribution of a growing medium is important because it determines pore space, gas exchange, and water-holding capacities; growing media with a high percentage of particles between 0.25 and $2.00 \mathrm{~mm}$ are optimal for potted plants in soilless culture (Brito et al., 2015; Jayasinghe, 2012a, 2012b). The results indicate that the combined addition of $\mathrm{CF}$ and $\mathrm{BV}$ to $\mathrm{CGW}$ increased the percentage of particles in the optimal range and that the highest percentage of particles in the optimal size range occurred when CGW was amended with $15 \% \mathrm{CF}$ and $1.0 \% \mathrm{BV}$. Because of its relatively coarse particle size and high surface area, CF may be particularly useful for obtaining a compost product with the desired particle sizes (Zhang et al., 2014). In addition, $\mathrm{CI}$ is related to particle-size distribution, and the increases in CI values have been positively correlated with improved physical properties of growing media (Zhang et al., 2014). Based on the particle-size distributions and CIs in the current study, the combined addition of CF and BV improved the size of the particles and the morphology and overall structure of CGW as a plant growing medium (Jayasinghe et al., 2010b).

PH, EC, AND CEC OF GROWING MEDIA. Nonamended CGW had an alkaline $\mathrm{pH}$ that was significantly $(P<$ 0.05 ) decreased by the addition of $\mathrm{CF}$ and/or BV (Table 1 ). The $\mathrm{pH}$ values of treatments $\mathrm{T} 5(15 \% \mathrm{CF}+0.5 \%$ $\mathrm{BV}), \mathrm{T} 6(15 \% \mathrm{CF}+1.0 \% \mathrm{BV}), \mathrm{T} 8$ $(25 \% \mathrm{CF}+0.5 \% \mathrm{BV})$, and T9 $(25 \%$ $\mathrm{CF}+1.0 \% \mathrm{BV}$ ) were in the optimal range for plant growth (Zhang et al., 2014). Similarly, the addition of CF and/or BV to the CGW greatly $(P<$ 0.05 ) reduced the EC value; the EC values of treatments $\mathrm{T} 5(15 \% \mathrm{CF}+$ $0.5 \% \mathrm{BV}), \mathrm{T} 6(15 \% \mathrm{CF}+1.0 \% \mathrm{BV})$, $\mathrm{T} 8(25 \% \mathrm{CF}+0.5 \% \mathrm{BV})$, and T9 $(25 \%$ $\mathrm{CF}+1.0 \% \mathrm{BV}$ ) were within the range that is suitable for plant growth (Zhang et al., 2014). Addition of CF or BV and especially the combined addition of CF and BV (treatments T5, T6, T8, and T9) greatly $(P<0.05)$ increased the $C E C$ value of the CGW; the CEC value was highest for treatment T9 $(25 \% \mathrm{CF}+1.0 \% \mathrm{BV})$ and was lowest for treatment $\mathrm{Tl}$.

$\mathrm{pH}$ affects the mobility and availability of nutrients in growing media 

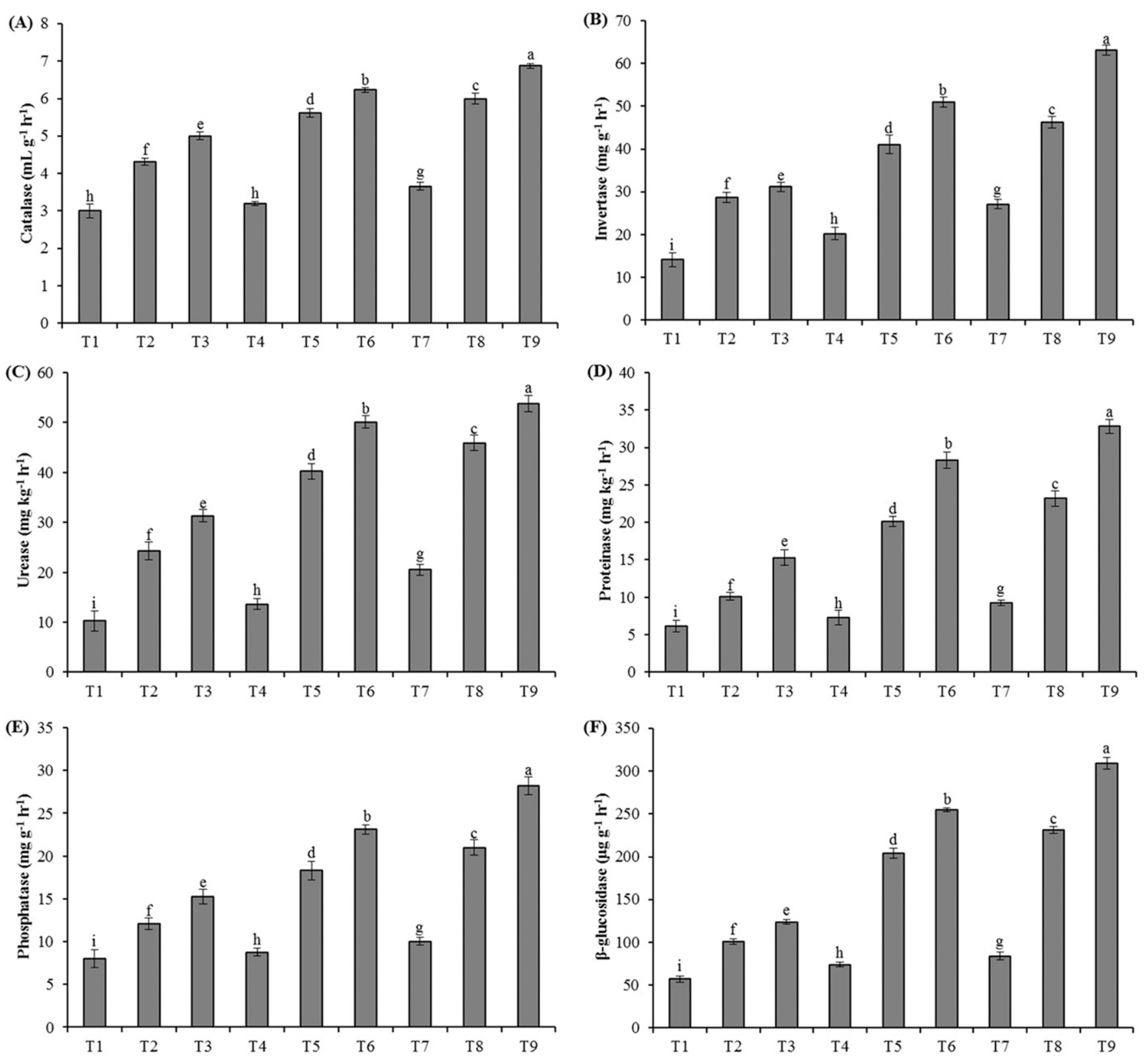

Fig. 2. Effects of coir fiber (CF) and bamboo vinegar (BV) on the activities of catalase (A), invertase (B), urease (C), proteinase (D), phosphatase $(\mathrm{E})$, and $\beta$-glucosidase $(\mathrm{F})$ in the nine growing media: $\mathrm{Tl}=$ nonamended treatment, $\mathrm{T} 2=0.5 \% \mathrm{BV}, \mathrm{T3}=1.0 \% \mathrm{BV}, \mathrm{T} 4=$ $15 \% \mathrm{CF}, \mathrm{T} 5=15 \% \mathrm{CF}+0.5 \% \mathrm{BV}, \mathrm{T} 6=15 \% \mathrm{CF}+1.0 \% \mathrm{BV}, \mathrm{T} 7=25 \% \mathrm{CF}, \mathrm{T} 8=25 \% \mathrm{CF}+0.5 \% \mathrm{BV}, \mathrm{T} 9=25 \% \mathrm{CF}+1.0 \% \mathrm{BV}$. Values are mean \pm SD $(n=30)$. Within each panel, means followed by different letters are significantly different according to least significant difference at $P \leq 0.05 ; 1 \mathrm{~mL} \cdot \mathrm{g}^{-1}=0.9586 \mathrm{fl} \mathrm{oz} / \mathrm{oz}, 1 \mathrm{mg} \cdot \mathrm{g}^{-1}=1000 \mathrm{ppm}, 1 \mathrm{mg} \cdot \mathrm{kg}^{-1}=1 \mathrm{ppm}, 1 \mu \mathrm{g} \cdot \mathrm{g}^{-1}=1 \mathrm{ppm}$.

(Zhang et al., 2014). EC is also important, because high salinity can limit seed germination and plant growth (Papafilippaki et al., 2015). $\mathrm{pH}$ and $\mathrm{EC}$ were lower for $\mathrm{CF}$ and BV than for the CGW (Table 1 ), and thus addition of $\mathrm{CF}$ and/or BV decreased the $\mathrm{pH}$ and EC of the CGW. Because it contains substantial quantities of organic acids, BV can neutralize alkaline substrates ( $\mathrm{Mu}$ et al., 2004). Also, by increasing medium aggregation and water movement, $\mathrm{CF}$ can increase the leaching of excessive soluble salts (Carlile et al., 2015).

CEC is a measure of the ability of the growing media to adsorb exchangeable cations; these exchangeable cations are available to the plant and resist leaching (Nieto et al., 2016). The above results indicate that addition of CF and BV can increase the CEC of CGW and thus enhance nutrient conservation of the CGW during plant growth; this is reasonable because CF is porous and has a high surface area and therefore attracts, retains, and exchanges basic cations (Hongpakdee and Ruamrungsri, 2015). BV, which contains high concentrations of macronutrients and exchangeable cations (such as exchangeable $\mathrm{Mg}$ ), also increased the CEC of the CGW; these results agree with those reported by Rattanawut (2014).

Nutrient CONTENTS OF GROWING MEDIA. Concentrations of macro- and micronutrients in the CGW tended to increase $(P<0.05)$ as the quantities of $\mathrm{CF}$ or $\mathrm{BV}$ added increased and especially when $\mathrm{CF}$ and $\mathrm{BV}$ 
were added together (Table 1). Nutrient contents were highest in treatment T9 $(25 \% \mathrm{CF}+1.0 \% \mathrm{BV})$, followed by treatments T6 $(15 \% \mathrm{CF}+1.0 \% \mathrm{BV})$, T8 (25\% CF + 0.5\% BV), and T5 (15\% $\mathrm{CF}+0.5 \% \mathrm{BV})$, all of which had been amended with both $\mathrm{CF}$ and $\mathrm{BV}$; the values were lowest in treatment $\mathrm{Tl}$.
These results indicate that the substantial quantities of macro- and micronutrients in the $\mathrm{CF}$ and $\mathrm{BV}$ increased the nutrient contents of the CGW, which agrees with the findings of Hongpakdee and Ruamrungsri (2015) and Mu et al. (2004). Rattanawut (2014) also reported that the considerable quantities

Table 4. Effects of CF and/or BV addition on the plant height, the length of the longest root, crown breadth, and leaf number for peacock arrowroot grown in the nine growing media (treatments T1-T9).

\begin{tabular}{|c|c|c|c|c|}
\hline & Plant ht $(\mathrm{cm})$ & $\begin{array}{c}\text { Longest } \\
\text { root length }(\mathrm{cm})\end{array}$ & $\begin{array}{c}\text { Crown } \\
\text { width }(\mathrm{cm})\end{array}$ & Leaves (no.) \\
\hline Treatment $^{\mathrm{z}}$ & \multicolumn{4}{|c|}{ Mean $(\text { SD })^{y}$} \\
\hline $\mathrm{Tl}$ & $42.9(1.8) \mathrm{i}^{\mathrm{x}}$ & $30.5(1.8) \mathrm{h}$ & $27.9(1.3) \mathrm{i}$ & $36(1) f$ \\
\hline $\mathrm{T} 2$ & $46.5(2.0) \mathrm{h}$ & $32.6(1.4) \mathrm{g}$ & $30.4(1.5) \mathrm{h}$ & $40(1) \mathrm{e}$ \\
\hline $\mathrm{T} 3$ & $53.9(1.4) \mathrm{e}$ & $37.3(1.0) \mathrm{e}$ & $36.2(1.7) \mathrm{e}$ & $44(2) d$ \\
\hline $\mathrm{T} 4$ & $52.2(2.3) \mathrm{f}$ & $35.0(1.1) \mathrm{f}$ & $34.7(1.2) \mathrm{f}$ & $43(3) \mathrm{d}$ \\
\hline $\mathrm{T} 5$ & $68.6(1.6) b$ & $48.7(1.3) b$ & $45.6(0.9) \mathrm{b}$ & $53(1) \mathrm{b}$ \\
\hline T6 & $70.2(1.1) \mathrm{a}$ & $50.4(1.1) \mathrm{a}$ & $48.5(1.1) \mathrm{a}$ & $56(1) \mathrm{a}$ \\
\hline $\mathrm{T} 7$ & $48.8(2.4) \mathrm{g}$ & $33.1(2.0) \mathrm{g}$ & $32.6(1.3) \mathrm{g}$ & $41(2) \mathrm{e}$ \\
\hline $\mathrm{T} 8$ & $62.7(1.3) \mathrm{d}$ & $43.9(1.7) \mathrm{d}$ & $42.8(1.1) \mathrm{d}$ & $50(2) c$ \\
\hline T9 & $65.3(2.6) c$ & $45.6(1.3) \mathrm{c}$ & $43.9(1.8) \mathrm{c}$ & $52(1) \mathrm{b}$ \\
\hline
\end{tabular}

$\mathrm{CF}=$ coir fiber $\mathrm{BV}=$ bamboo vinegar

${ }^{\mathrm{z}} \mathrm{Tl}=$ nonamended treatment, $\mathrm{T} 2=0.5 \% \mathrm{BV}, \mathrm{T} 3=1.0 \% \mathrm{BV}, \mathrm{T} 4=15 \% \mathrm{CF}, \mathrm{T} 5=15 \% \mathrm{CF}+0.5 \% \mathrm{BV}, \mathrm{T} 6=15 \%$ $\mathrm{CF}+1.0 \% \mathrm{BV}, \mathrm{T} 7=25 \% \mathrm{CF}, \mathrm{T} 8=25 \% \mathrm{CF}+0.5 \% \mathrm{BV}, \mathrm{T} 9=25 \% \mathrm{CF}+1.0 \% \mathrm{BV}$.

${ }^{y}$ Values are mean \pm SD $(\mathrm{n}=30) ; 1 \mathrm{~cm}=0.3937$ inch.

${ }^{\mathrm{x}}$ Means in a column followed by the same letter are not significantly different at $P \leq 0.05$ by least significant difference.

of nutrients in BV could greatly offset the nutrient deficiencies of growing media. The adherence of nutrients to $\mathrm{CF}$ surfaces and pores could also reduce nutrient leaching and therefore enhance nutrient availability in the CGW (Carlile et al., 2015). In addition, CF and BV have high CEC and could therefore increase the ion exchange capacities of the CGW and thus increase its nutrientpreserving capability (Hongpakdee and Ruamrungsri, 2015).

As noted above in the Materials and Methods (see Preparation of Growing Media), this study did not include a fertilized control in which the compost was amended with conventional commercial fertilizers. Future experiments should consider the inclusion of this treatment for comparison purposes.

Microbial numbers in the GROWING MEDIA. Addition of CF and BV significantly $(P<0.05)$ increased the numbers of culturable bacteria, actinomycetes, and fungi in the growing media (Fig. 1). The microbial numbers were greater in treatments $\mathrm{T} 5$ $(15 \% \mathrm{CF}+0.5 \% \mathrm{BV}), \mathrm{T} 6(15 \% \mathrm{CF}+$ $1.0 \% \mathrm{BV}), \mathrm{T} 8(25 \% \mathrm{CF}+0.5 \% \mathrm{BV})$,
(A)

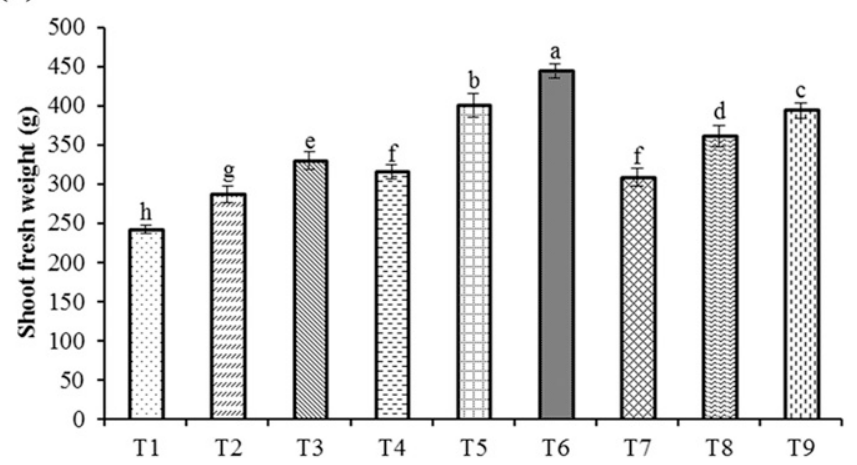

(C)

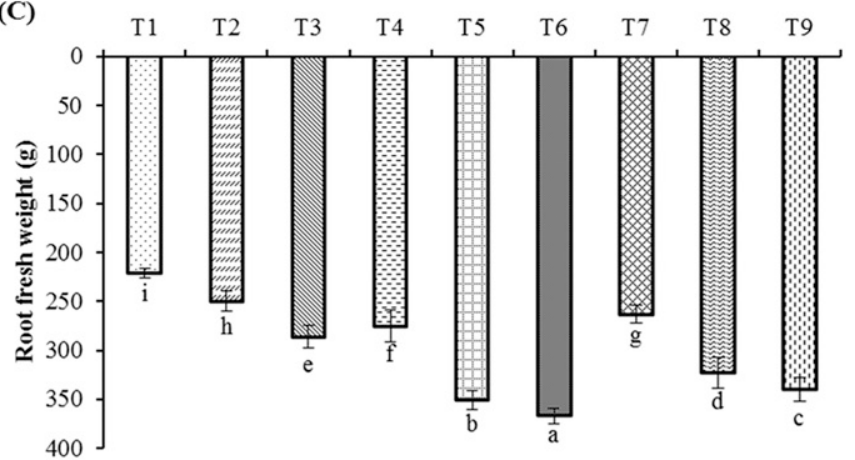

(B)

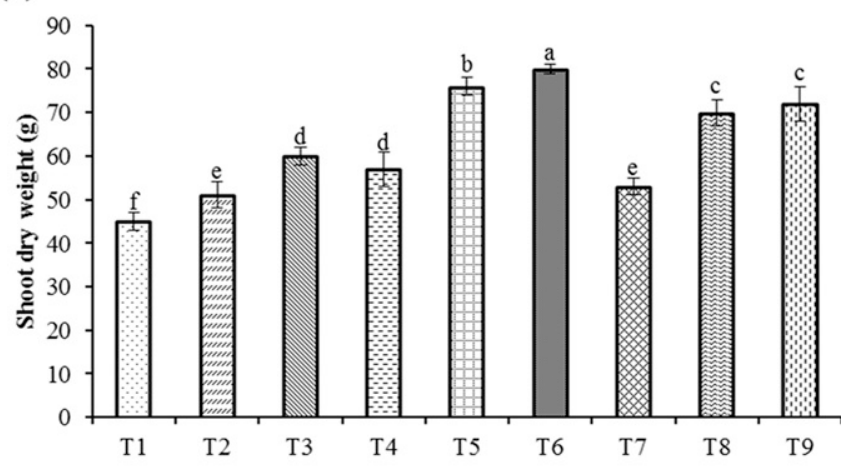

(D)

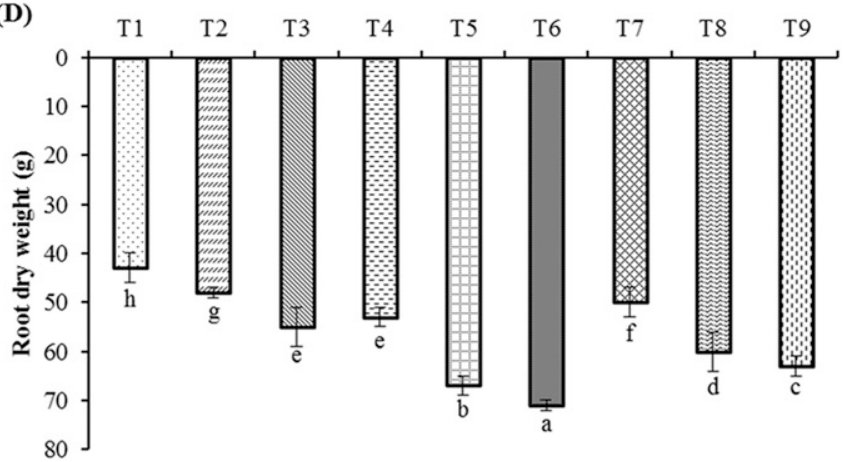

Fig. 3. Shoot fresh weight (A), shoot dry weight (B), root fresh weight (C), and root dry weight (D) of peacock arrowroot as affected by the nine growing media: $\mathrm{T} 1=$ nonamended treatment, $\mathrm{T} 2=0.5 \% \mathrm{BV}, \mathrm{T} 3=1.0 \% \mathrm{BV}, \mathrm{T} 4=15 \% \mathrm{CF}, \mathrm{T} 5=15 \% \mathrm{CF}+0.5 \%$ BV, T6 $=15 \% \mathrm{CF}+1.0 \% \mathrm{BV}, \mathrm{T} 7=\mathbf{2 5} \% \mathrm{CF}, \mathrm{T} 8=\mathbf{2 5} \% \mathrm{CF}+\mathbf{0 . 5 \%} \mathrm{BV}, \mathrm{T} 9=\mathbf{2 5} \% \mathrm{CF}+\mathbf{1 . 0} \% \mathrm{BV}$. Values are mean $\pm \mathrm{SD}(\mathrm{n}=\mathbf{3 0})$. Within each panel, means followed by different letters are significantly different according to least significant difference at $P \leq 0.05$; $1 \mathrm{~g}=0.0353 \mathrm{oz}$. 
Table 5. Effects of CF and/or BV addition on the properties of root systems of peacock arrowroot grown in the nine growing media (treatments T1-T9).

\begin{tabular}{|c|c|c|c|c|c|}
\hline \multirow[b]{2}{*}{ Treatment $^{\mathrm{z}}$} & Total root length $(\mathrm{cm})$ & Total root surface area $\left(\mathrm{cm}^{2}\right)$ & Root diam (mm) & Total root vol $\left(\mathrm{cm}^{3}\right)$ & Root tips (no.) \\
\hline & \multicolumn{5}{|c|}{ Mean $(S D)^{y}$} \\
\hline $\mathrm{Tl}$ & $733(14) \mathrm{i}^{\mathrm{x}}$ & $360.06(18.20) \mathrm{i}$ & $1.42(0.67) \mathrm{i}$ & $15.23(0.98) \mathrm{i}$ & $4833(72) \mathrm{i}$ \\
\hline $\mathrm{T} 3$ & $934(20) \mathrm{e}$ & $442.22(28.59) \mathrm{e}$ & $1.72(0.41) \mathrm{e}$ & $20.18(1.02) \mathrm{e}$ & $6820(34)$ e \\
\hline $\mathrm{T} 4$ & $910(22) \mathrm{f}$ & $420.38(31.26) \mathrm{f}$ & $1.67(0.51) \mathrm{f}$ & $18.33(0.65) \mathrm{f}$ & $6519(56) \mathrm{f}$ \\
\hline $\mathrm{T} 5$ & $1196(10) b$ & $498.45(30.98) b$ & $2.13(0.90) \mathrm{b}$ & $26.03(1.11) b$ & $7930(60) b$ \\
\hline T8 & $1009(16) \mathrm{d}$ & $468.91(24.04) \mathrm{d}$ & $1.91(0.34) \mathrm{d}$ & $23.98(1.20) \mathrm{d}$ & $7318(67) d$ \\
\hline T9 & $1138(13) \mathrm{c}$ & $473.66(16.39) \mathrm{c}$ & $2.02(0.26) \mathrm{c}$ & $25.11(0.83) \mathrm{c}$ & $7521(70) \mathrm{c}$ \\
\hline
\end{tabular}

$\mathrm{CF}=$ coir fiber; $\mathrm{BV}=$ bamboo vinegar.

${ }^{\mathrm{z}} \mathrm{Tl}=$ nonamended treatment, $\mathrm{T} 2=0.5 \% \mathrm{BV}, \mathrm{T} 3=1.0 \% \mathrm{BV}, \mathrm{T} 4=15 \% \mathrm{CF}, \mathrm{T} 5=15 \% \mathrm{CF}+0.5 \% \mathrm{BV}, \mathrm{T} 6=15 \% \mathrm{CF}+1.0 \% \mathrm{BV}, \mathrm{T} 7=25 \% \mathrm{CF}, \mathrm{T} 8=25 \% \mathrm{CF}+0.5 \% \mathrm{BV}, \mathrm{T} 9=25 \%$ $\mathrm{CF}+1.0 \% \mathrm{BV}$.

Values are mean $\pm \mathrm{SD}(\mathrm{n}=30) ; \mathrm{l} \mathrm{cm}=0.3937$ inch, $1 \mathrm{~cm}^{2}=0.1550$ inch $^{2}, 1 \mathrm{~mm}=0.0394$ inch, $1 \mathrm{~cm}^{3}=0.0610$ inch $^{3}$.

${ }^{\mathrm{x}}$ Means in a column followed by the same letter are not significantly different at $P \leq 0.05$ by least significant difference.

and $\mathrm{T} 9(25 \% \mathrm{CF}+1.0 \% \mathrm{BV})$ (with the combined addition of $\mathrm{CF}$ and $\mathrm{BV}$ ) than in the other treatments; the numbers were highest in treatment T9 $(25 \% \mathrm{CF}+1.0 \% \mathrm{BV})$ and lowest in treatment $\mathrm{Tl}$.

The microorganisms in the growing media improve media structure and enhance organic matter decomposition and nutrient cycling and retention (Zhang et al., 2014). The high microbial numbers in the CGW amended with $\mathrm{CF}$ and BV addition could both fix and mineralize more media nutrients and contribute to aggregate formation. Similar observations were made by Anderson and Domsch (2010) and Du et al. (2015). Abundant microbial communities are also associated with microbiostasis, which can prevent the germination of spores of nutrient-dependent pathogens, indicating that disease suppression could be an additional benefit of adding CF and BV to CGW (Borrero et al., 2009; Xue and Huang, 2013).

ENZYME ACTIVITIES IN THE GROWING MEDIA. The activities of catalase, invertase, urease, proteinase, phosphatase, and $\beta$-glucosidase in CGW increased greatly $(P<0.05)$ with $\mathrm{CF}$ and BV addition (Fig. 2). The trends for enzyme activities were similar to those for microbial numbers. Enzyme activities were higher in treatments $\mathrm{T} 5(15 \% \mathrm{CF}+0.5 \% \mathrm{BV})$, T6 (15\% CF + 1.0\% BV), T8 (25\% CF $+0.5 \% \mathrm{BV})$, and T9 $(25 \% \mathrm{CF}+1.0 \%)$ than in the other treatments. Enzyme activities were highest in treatment T9 $(25 \% \mathrm{CF}+1.0 \% \mathrm{BV})$ and lowest in treatment $\mathrm{Tl}$.

The increase in enzyme activities with addition of $\mathrm{CF}$ and $\mathrm{BV}$ is likely to enhance the mineralization of nutrients and the sustainable use of CGW as a soilless medium. Catalase is an oxidoreductase that can protect roots from the damage caused by reactive oxygen species (Garcia-Gil et al., 2000). Reports have also shown that catalase activity was inhibited by an unfavorable media environment (Xue and Huang, 2013). In this study, the addition of $\mathrm{CF}$ or $\mathrm{BV}$ and especially the combined addition of $\mathrm{CF}$ and $\mathrm{BV}$ to CGW increased catalase activity, which is likely to balance the rhizosphere environment and promote the growth and development of plants.

Many enzymes are also positively related to growing media fertility (Borrero et al., 2009). Invertase, urease, proteinase, phosphatase, and $\beta$-glucosidase are able to degrade complex organic compounds into available nutrients. The results showed that the use of CF and BV greatly increased the activities of these enzymes in the CGW, and were thus likely to have increased the nutrients available to plants growing in the CGW.

Plant biomass production. Biomass production of peacock arrowroot was significantly $(P<0.05)$ increased by addition of $\mathrm{CF}$ or $\mathrm{BV}$ alone and especially by the combined addition of CF and BV (Table 4; Fig. 3). Dry weights of shoots and roots were highest with treatment T6 (15\% CF + $1.0 \% \mathrm{BV})$ and lowest with treatment Tl (Fig. 3). Similar results were obtained for plant height, length of the longest root, crown breadth, and leaf number (Table 4). Compared with treatment $\mathrm{Tl}$, treatment $\mathrm{T} 6$ $(15 \% \mathrm{CF}+1.0 \% \mathrm{BV})$ increased shoot fresh weight, shoot dry weight, root fresh weight, root dry weight, plant height, longest root length, crown breadth, and number of leaves by $83.9 \%, 77.8 \%, 66.1 \%, 65.1 \%, 63.6 \%$, $65.2 \%, 73.8 \%$, and $55.6 \%$, respectively.

The addition of CF and BV to CGW may have increased the growth and affected the morphology of peacock arrowroot because these amendments increased aeration, water permeability, and water retention; improved the structure of CGW; and reduced nutrient leaching (Carlile et al., 2015; Jayasinghe et al., 2010c; $\mathrm{Mu}$ et al., 2004). As mentioned before, $\mathrm{CF}$ and $\mathrm{BV}$ also contain and provide nutrients, and this evidently contributed to the improved growth of peacock arrowroot (Hongpakdee and Ruamrungsri, 2015; Mu et al., 2004). Sufficient nutrient supply can greatly affect plant morphology, and increasing the supply of $\mathrm{N}$, phosphorus $(\mathrm{P}), \mathrm{K}$, calcium $(\mathrm{Ca}), \mathrm{Mg}$, and iron $(\mathrm{Fe})$ by addition of $\mathrm{CF}$ and $\mathrm{BV}$ to the CGW likely enhanced shoot and root growth (Hongpakdee and Ruamrungsri, 2015; Zhang et al., 2013a). BV may have also increased plant growth by inhibiting the growth of pathogenic bacteria and accelerating the growth of beneficial bacteria (Mun and $\mathrm{Ku}$, 2010).

RoOT GROWTH. The effects of treatments on peacock arrowroot root system properties were similar to the effects of treatments on plant biomass (Table 5). Total root length, total root surface area, average root diameter, total root volume, and total number of root tips were greater $(P<0.05)$ when CGW was amended with $\mathrm{CF}$ and/or BV. The values for these properties were highest in treatments T5 
Table 6. Effects of CF and/or BV addition on the contents of photosynthetic pigments, water, and macro- and micronutrients (based on oven-dried weight) of leaves of peacock arrowroot in the nine growing media (treatments T1-T9).

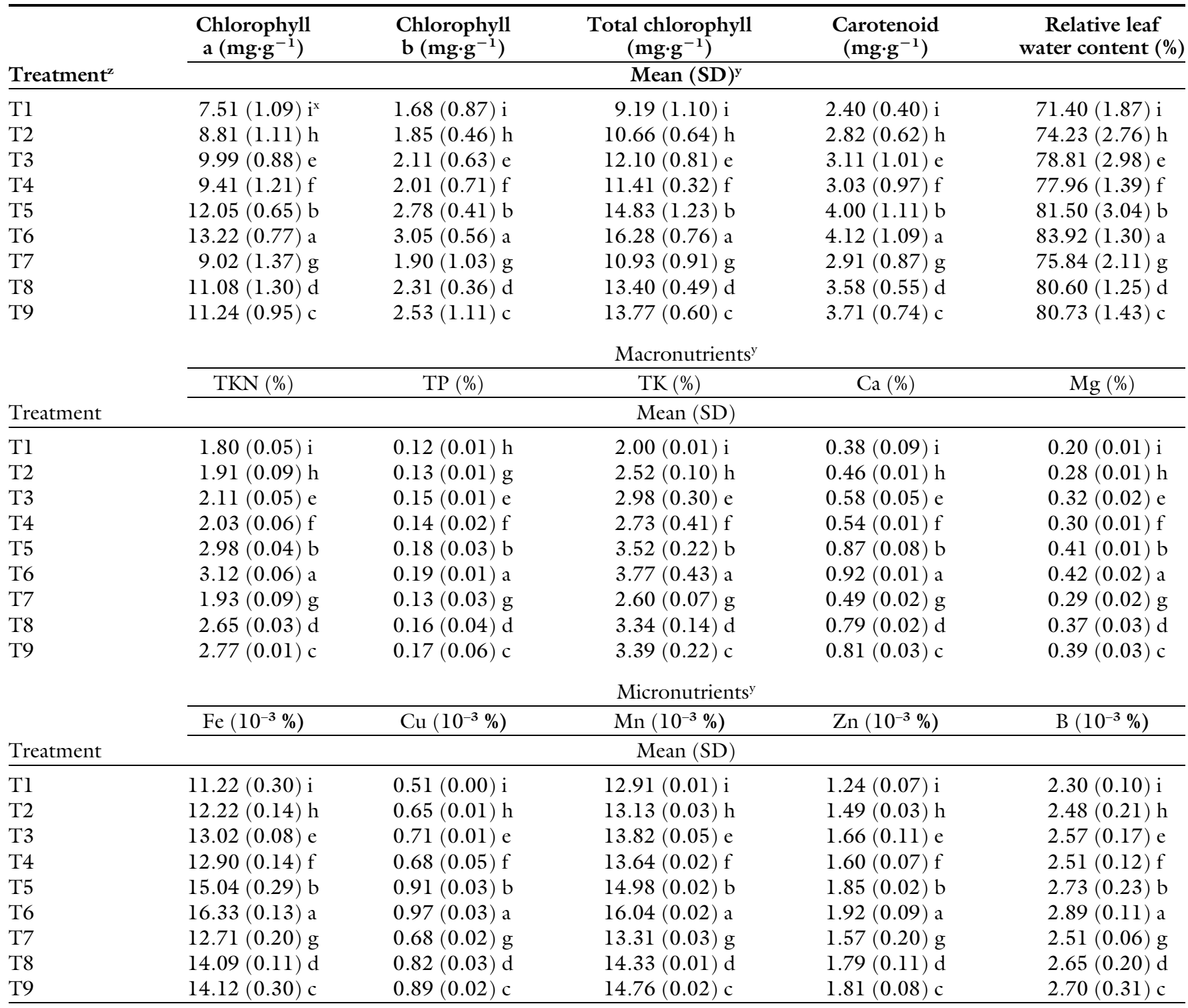

$\mathrm{CF}=$ coir fiber; $\mathrm{BV}=$ bamboo vinegar; Total chlorophyll $=$ chlorophyll $\mathrm{a}+$ chlorophyll $\mathrm{b}+$ carotenoid; $\mathrm{TKN}=$ total Kjeldahl nitrogen; $\mathrm{TP}=$ total phosphorus; $\mathrm{TK}=$ total potassium; $\mathrm{Ca}=$ calcium $; \mathrm{Mg}=$ magnesium; $\mathrm{Fe}=$ iron; $\mathrm{Cu}=$ copper $\mathrm{Mn}=$ manganese $\mathrm{Zn}=$ zinc $; \mathrm{B}=$ boron .

${ }^{\mathrm{z}} \mathrm{Tl}=$ nonamended treatment, $\mathrm{T} 2=0.5 \% \mathrm{BV}, \mathrm{T} 3=1.0 \% \mathrm{BV}, \mathrm{T} 4=15 \% \mathrm{CF}, \mathrm{T} 5=15 \% \mathrm{CF}+0.5 \% \mathrm{BV}, \mathrm{T} 6=15 \% \mathrm{CF}+1.0 \% \mathrm{BV}, \mathrm{T} 7=25 \% \mathrm{CF}, \mathrm{T} 8=25 \% \mathrm{CF}+0.5 \% \mathrm{BV}, \mathrm{T} 9=25 \%$ $\mathrm{CF}+1.0 \% \mathrm{BV}$

${ }^{\mathrm{y}} 1 \mathrm{mg} \cdot \mathrm{g}^{-1}=1000 \mathrm{ppm}$.

${ }^{x}$ Values are mean \pm SD $(n=30)$. Means in a column followed by the same letter are not significantly different at $P \leq 0.05$ by least significant difference.

$(15 \% \mathrm{CF}+0.5 \% \mathrm{BV}), \mathrm{T} 6(15 \% \mathrm{CF}+$ $1.0 \% \mathrm{BV})$, T8 (25\% CF + 0.5\% BV), and T9 $(25 \% \mathrm{CF}+1.0 \% \mathrm{BV})$ (with the combined addition of $\mathrm{CF}$ and $\mathrm{BV}$ ) than in the other treatments. The values were highest in treatment $\mathrm{T} 6$ $(15 \% \mathrm{CF}+1.0 \% \mathrm{BV})$ and lowest in treatment Tl. Compared with the treatment $\mathrm{Tl}$, treatment $\mathrm{T} 6(15 \% \mathrm{CF}+$ $1.0 \% \mathrm{BV}$ ) increased the total root length, total root surface area, average root diameter, total root volume, and total number of root tips by $77.6 \%$, $53.8 \%, 59.9 \%, 78.1 \%$, and $70.8 \%$, respectively.
The above results indicate that CGW amended with both CF and $\mathrm{BV}$, and especially with $15 \% \mathrm{CF}$ and $1.0 \% \mathrm{BV}$, resulted in progressive increases in these morphological parameters of the roots in peacock arrowroot. The increases in these parameters with addition of $\mathrm{CF}$ and BV could be attributed to the improvements in the physical and chemical properties of the CGW. According to Zhang et al. (2014), a high $\mathrm{pH}$ value and a high salt concentration (EC value) inhibit root growth and reduce the efficiency with which water and nutrients are transported from roots to shoots. As noted earlier, $\mathrm{CF}$ and BV addition decreased the $\mathrm{pH}$ and $\mathrm{EC}$ values of CGW, which reduced acidbase imbalance and salt stress. CF and BV could also enhance root growth by increasing nutrient supply and storage (Hongpakdee and Ruamrungsri, 2015; Mu et al., 2004). The amendments may also have enhanced root growth by improving the physical characteristics of the CGW (Nieto et al., 2016; Zhang et al., 2014).

Plant leaf growth. All treatments but especially treatments T5 
$(15 \% \mathrm{CF}+0.5 \% \mathrm{BV})$, T6 $(15 \% \mathrm{CF}+$ $1.0 \% \mathrm{BV}), \mathrm{T} 8(25 \% \mathrm{CF}+0.5 \% \mathrm{BV})$, and T9 $(25 \% \mathrm{CF}+1.0 \% \mathrm{BV})$ (with addition of both $\mathrm{CF}$ and $\mathrm{BV}$ ) significantly $(P<0.05)$ increased the photosynthetic pigments, water, and nutrients in peacock arrowroot leaves (Table 6). The values were highest in treatment T6 $(15 \% \mathrm{CF}+1.0 \% \mathrm{BV})$ and lowest in treatment $\mathrm{Tl}$.

Relative leaf water content is a good indicator of plant water balance and is related to many physiological parameters such as growth, photosynthesis, stomatal conductance, transpiration, and respiration (Jayasinghe et al., 2010a; Papafilippaki et al., 2015). The above results indicate that $\mathrm{CF}$ and $\mathrm{BV}$ not only increased relative leaf water content and water-use efficiency and enhanced leaf physiology but also increased watersoluble nutrient concentrations and reduced nutrient losses, thereby enhancing plant growth. Other studies have also shown that $\mathrm{CF}$ or $\mathrm{BV}$ can increase the ability of plants to store water (Du et al., 2015; Hongpakdee and Ruamrungsri, 2015).

The positive effects of $\mathrm{CF}$ and $\mathrm{BV}$ on chlorophyll formation and photosynthesis and on nutrient concentrations in leaves have been attributed to the increased relative leaf water content and to the increased supply of available nutrients (Hongpakdee and Ruamrungsri, 2015; Mu et al., 2004). These results also indicate that $\mathrm{CF}$ and BV amendments might eliminate or reduce the need for additional mineral fertilizers in the production of potted plants. The positive effects of $\mathrm{CF}$ and $\mathrm{BV}$ could also be due to the increases in microbial numbers and enzyme activities in the CGW; microorganisms and enzymes could accelerate the release of nutrients in the growing medium and could therefore accelerate photosynthetic pigment synthesis and increase the nutrient contents of peacock arrowroot leaves (Young et al., 2014).

\section{Conclusions}

This study provides new information concerning the use of growing media without peat for the cultivation of ornamental plants. It is the first study to report on the combined effects of $\mathrm{CF}$ and $\mathrm{BV}$ on the physical, chemical, microbiological, and nutritional properties of CGW and on the ability of CGW to support the growth of peacock arrowroot. CGW properties were significantly improved and peacock arrowroot growth was significantly enhanced when CGW was amended with a combination of $\mathrm{CF}$ and $\mathrm{BV}$; the best results were obtained with a combination of $15 \% \mathrm{CF}$ and $1.0 \% \mathrm{BV}$. CF and $\mathrm{BV}$ addition increased the aeration and water permeability of the CGW, increased the capacity of CGW to store water and nutrients, and increased microbial numbers and enzyme activities in the CGW. The findings indicate that, when amended with a combination of $\mathrm{CF}$ and $\mathrm{BV}$, CGW is a viable substitute for peat in the soilless culture of ornamental plants in pots. Three points concerning the practical application of this research are presented in the following: 1) The selection of materials: the CGW product should be evaluated to determine its maturity and other properties, i.e., the compost product should have a germination index $>80 \%$, C: $N$ ratio $<20$, EC value $<4 \mathrm{mS} \cdot \mathrm{cm}^{-1}$, and $\mathrm{CEC}$ value $>60.0$ $\mathrm{cmol} \cdot \mathrm{kg}^{-1}$. The air-dried CF should be cut to a length of 3 to $5 \mathrm{~cm}$ before it is added to the CGW because particle sizes in this range favor aeration, water permeability, and water retention of the CGW. Before the $\mathrm{BV}$ is added to the CGW, it should be diluted in water so that it can be uniformly mixed with the CGW; 2 ) The preparation of growing media: because the loss of primary porosity is generally caused by compaction, the growing media should not be compacted when they are added to the pots; 3) The control of greenhouse conditions: during the growth of peacock arrowroot, the greenhouse should be maintained at 20 to $25^{\circ} \mathrm{C}$ in the day and 18 to $20^{\circ} \mathrm{C}$ at night, at $65 \%$ to $75 \%$ relative humidity, and at $18 \mathrm{~mol} \cdot \mathrm{m}^{-2} \cdot \mathrm{d}^{-1}$ light intensity.

\section{Literature cited}

Aggarwal, S. and C. Nirmala. 2012. Utilization of coir fibers as an eco-friendly substitute for costly gelling agents for in vitro orchid seed germination. Sci. Hort. 133:89-92.

Ahmad, L., A. Ahmad, S. Ahmad, A. Amjad, M. Saleem, and A. Akram. 2012. Effect of various agricultural substrates on biometric and qualitative characteristics of Ruscus bypophyllum. Intl. J. Agr. Biol. 14:116-120.
Anderson, T.H. and K.H. Domsch. 2010. Soil microbial biomass: The eco-physiological approach. Soil Biol. Biochem. 42:20392043.

Awang, Y. and M. Ismail. 1997. The growth and flowering of some annual ornamentals on the coconut dust. Acta Hort. 450:31-38

Boldrin, A., K.R. Hartling, M. Laugen, and T.H. Christensen. 2010. Environmental inventory modelling of the use of compost and peat in growth media preparation. Resources Conserv. Recycling 54:1250-1260.

Borrero, C., I. Trillas, and M. Aviles. 2009. Carnation fusarium wilt suppression in four composts. Eur. J. Plant Pathol. 123:425-433.

Brito, L.M., M. Reis, I. Mourao, and J. Coutinho. 2015. Use of acacia waste compost as an alternative component for horticultural substrates. Commun. Soil Sci. Plant Anal. 46:1814-1826.

Carlile, W.R., C. Cattivello, and P. Zaccheo. 2015. Organic growing media: Constituents and properties. Vadose Zone J. 14:doi: 10.2136/vzj2014.09.0125.

Cesaro, A., V. Belgiorno, and M. Guida. 2015. Compost from organic solid waste: Quality assessment and European regulations for its sustainable use. Resources Conserv. Recycling 94:72-79.

Chen, Y.X., X.D. Huang, Z.Y. Han, X. Huang, B. Hu, D.Z. Shi, and W.X. Wu. 2010. Effects of bamboo charcoal and bamboo vinegar on nitrogen conservation and heavy metals immobility during pig manure composting. Chemosphere 78:1177-1181.

De Lucia, B., G. Cristiano, L. Vecchietti, and L. Bruno. 2013. Effect of different rates of composted organic amendment on urban soil properties, growth and nutrient status of three Mediterranean native hedge species. Urban For. Urban Green. 12:537-545

Du, N.S., L. Shi, L.T. Du, Y.H. Yuan, B. Li, T. Sang, J. Sun, S. Shu, and S.R. Guo. 2015. Effect of vinegar residue compost amendments on cucumber growth and fusarium wilt. Environ. Sci. Pollution Resource 22:19133-19141.

Eksi, M., D.B. Rowe, R. FernandezCanero, and B.M. Cregg. 2015. Effect of substrate compost percentage on green roof vegetable production. Urban For. Urban Green. 14:315-322.

Fernandez-Hernandez, A., A. Roig, N. Serramia, C.G. Civantos, and M.A. Sanchez-Monedero. 2014. Application of compost of two-phase olive mill waste on olive grove: Effects on soil, olive fruit 
and olive oil quality. Waste Mgt. 34:11391147.

Gabhane, J., S.P.M.P. William, R. Bidyadhar, P. Bhilawe, D. Anand, A.N. Vaidya, and S.R. Wate. 2012. Additives aided composting of green waste: Effects on organic matter degradation, compost maturity, and quality of the finished compost. Bioresour. Technol. 114:382388.

Garcia-Gil, J.C., C. Plaza, P. Soler-Rovira, and A. Polo. 2000. Long-term effects of municipal solid waste compost application on soil enzyme activities and microbial biomass. Soil Biol. Biochem. 32:19071913.

Hongpakdee, P. and S. Ruamrungsri. 2015. Water use efficiency, nutrient leaching, and growth in potted marigolds affected by coconut coir dust amended in substrate media. Hort. Environ. Biotechnol. 56:27-35.

Jayasinghe, G.Y. 2012a. Synthetic soil aggregates as a potting medium for ornamental plant production. J. Plant Nutr. 35:1441-1456.

Jayasinghe, G.Y. 2012b. Sugarcane bagasses sewage sludge compost as a plant growth substrate and an option for waste management. Clean Technol. Environ. 14:625-632.

Jayasinghe, G.Y., I.D.L. Arachchi, and Y. Tokashiki. 2010a. Evaluation of containerized substrates developed from cattle manure compost and synthetic aggregates for ornamental plant production as a peat alternative. Resources Conserv. Recycling 54:1412-1418.

Jayasinghe, G.Y., Y. Tokashiki, I.D.L. Arachchi, and M. Arakaki. 2010c. Sewage sludge sugarcane trash based compost and synthetic aggregates as peat substitutes in containerized media for crop production. J. Hazard. Mater. 174:700706.
Jayasinghe, G.Y., Y. Tokashiki, and M. Kitou. 2010b. Use of synthetic soil aggregates as a containerized growth medium component to substitute peat in the ornamental plant production. Arch. Agron. Soil Sci. 56:183-199.

Jayasinghe, G.Y., Y. Tokashiki, M. Kitou, and K. Kinjo. 2009. Coal fly ash-based synthetic aggregates as potential alternative container substrates for ornamentals. J. Plant Nutr. Soil Sci. 172:720-728.

Koch, K. and W. Barthlott. 2009. Superhydrophobic and superhydrophilic plant surfaces: An inspiration for biomimetic materials. Philosophical Trans. Royal Soc. A 367:1487-1509.

Mu, J., T. Uehara, and T. Furuno. 2004. Effect of bamboo vinegar on regulation of germination and radical growth of seed plants II: Composition of moso bamboo vinegar at different collection temperature and its effects. J. Wood Sci. 50:470-476.

Mun, S.P. and C.S. Ku. 2010. Pyrolysis GC-MS analysis of tars formed during the aging of wood and bamboo crude vinegars. J. Wood Sci. 56:47-52.

Nieto, A., G. Gasco, J. Paz-Ferreiro, J.M. Fernandez, C. Plaza, and A. Mendez. 2016. The effect of pruning waste and biochar addition on brown peat based growing media properties. Sci. Hort. 199:142-148.

Papafilippaki, A., N. Paranychianakis, and N.P. Nikolaidis. 2015. Effects of soil type and municipal solid waste compost as soil amendment on Cichorium spinosum (spiny chicory) growth. Sci. Hort. 195:195-205.

Rattanawut, J. 2014. Effects of dietary bamboo charcoal powder including bamboo vinegar liquid supplementation on growth performance, fecal microflora population and intestinal morphology in betong chickens. Jpn. Poult. Sci. 51:165-171.

Ronga, D., C. Pane, M. Zaccardelli, and N. Pecchioni. 2016. Use of spent coffee ground compost in peat-based growing media for the production of basil and tomato potting plants. Commun. Soil Sci. Plant Anal. 47:356-368.

Sen, B. and T.S. Chandra. 2009. Do earthworms affect dynamics of functional response and genetic structure of microbial community in a lab-scale composting system? Bioresour. Technol. 100:804811.

Shi, J.G., G.M. Zeng, X.Z. Yuan, F. Dai, J. Liu, and X.H. Wu. 2006. The stimulatory effects of surfactants on composting of waste rich in cellulose. World J. Microbiol. Biotechnol. 22:1121-1127.

Tran, P.L., J.S. Lee, and K.H. Park. 2013. Molecular structure and rheological character of high-amylose water caltrop (Trapa bispinosa Roxb.) starch. Food Sci. Biotechnol. 22:979-985.

Xue, D. and X.D. Huang. 2013. The impact of sewage sludge compost on tree peony growth and soil microbiological, and biochemical properties. Chemosphere 93:583-589.

Young, T., D.D. Cameron, J. Sorrill, T. Edwards, and G.K. Phoenix. 2014. Importance of different components of green roof substrate on plant growth and physiological performance. Urban For. Urban Green. 13:507-516.

Zhang, L., X.Y. Sun, Y. Tian, and X.Q. Gong. 2013a. Effects of brown sugar and calcium superphosphate on the secondary fermentation of green waste. Bioresour. Technol. 131:68-75.

Zhang, L., X.Y. Sun, Y. Tian, and X.Q. Gong. 2013b. Composted green waste as a substitute for peat in growth media:Effects on growth and nutrition of Calathea insignis. PLoS One 8:e78121.

Zhang, L., X.Y. Sun, Y. Tian, and X.Q. Gong. 2014. Biochar and humic acid amendments improve the quality of composted green waste as a growth medium for the ornamental plant Calathea insignis. Sci. Hort. 176:70-78. 